\title{
Analisis Wacana Isi Pesan Iklan Politik Pemilihan Kepala Daerah DKI Jakarta Di Media Internet
}

\author{
Redyta Septiani \\ (redytaseptiani41@gmail.com)
}

\begin{abstract}
Redyta Septiani, G.311.09.0042. Discourse Analysis of Political Advertising Message Jakarta Regional Head Election in Media Internet.Thesis : Study Programme S - 1 Communication Science University Semarang.

The purpose of this study was to analyze the discourse on political advertising message content Jakarta Regional Head Election delivered via the Internet. This type of research is qualitative. The data in this study is qualitative data (data that is without the numbers or numbers ), so the data is then analyzed substantive category by reference, reference, and scientific references ).

The foundation of the theory used in this research adopt from Denis McQuail ( 2011) which states characterless new medi, not only the diversity and uncertainty in the future, but also because of the character that is postmodern. The question in this study is how the political message content on the internet.

The method used in this study is a discourse analysis method proposed by Fairclough. Discourse analysis is used to analyze the languages used in a social phenomenon as well as simple things that exist in everyday society. Sources of data used in this study is the primary data source in the political ads on the internet, Secondary data source is data obtained from the study of literature, the website as a reference and a data amplifier, and mass media information associated with the object of writing this.It was concluded that the content of political advertising messages local election Jakarta Jokowi - Ahok on the internet have text isiya able to attract audiences of Internet users with short text.
\end{abstract}

Kata Kunci : Analisis Wacana, Iklan Politik, Teks, Internet, New Medium Theory

\section{PENDAHULUAN}

Di era globalisasi ini media massa internet memiliki keunggulan dalam kecepatan penayangan yang isinya lebih bervariatif dan berdaya jangkau luas, dapat diakses seluruh audien diseluruh dunia. Internet menjadi jendela informasi global, tidak hanya di Indonesia tapi diseluruh belahan dunia, yang dulunya sangat sulit dijangkau dengan perantara media cetak dan media elektronik. Internet kini sangat digemari oleh setiap orang, dari anak kecil sampai orang dewasa. sekarang internet telah berkembang menjadi ajang komunikasi yang sangat efektif, sehingga telah menyimpang jauh dari misi awalnya. Kemudahan-kemudahan inilah yang kemudian dimanfaatkan oleh pengusaha-pengusaha iklan dalam menawarkan berbagai macam produk iklan yang mereka tawarkan. Internet mengubah bentuk masyarakat dari masyarakat dunia lokal menjadi masyarakat dunia global.

Sebuah dunia yang sangat transparan terhadap perkembangan teknologi dan informasi yang begitu 
cepat dan besar. Industri media baru (internet) selain menyediakan informasi - informasi yang diperlukan, internet juga sebagai ajang hiburan. Kini internet juga dapat mempengaruhi institusi politik, sosial, dan budaya. Saat ini internet menjadi salah satu wahana yang berperan penting di dalam menyampaikan orasi politik. Media massa internet masih akan terus berkembang dan dipakai oleh pihakpihak yang bersangkutan termasuk para calon kandidat partai politik untuk menaikan rating citra mereka. Untuk itu, para elit politik akan memanfaatkan kesempatan besar ini dalam mempengaruh khalayak melalui orasiorasi politik mereka. Iklan politik melalui internet akan menyajikan tentang visi-misi atau pun tujuan, pesanpesandan program para calon kandidat. Seperti yang dilakukan oleh pasangan Jokowi-Ahok dalam pemilihan Gubernur DKI Jakarta lalu, mereka tidak hanya beriklan melalui media cetak, baliho, pamflet, dan media elektonik (seperti televisi) yang caranya sudah klasik. Pasangan ini memanfaatkan media baru internet untuk melakukan kampanye yang tidak mengeluarkan biaya yang banyak. Cukup memasang iklan web, blog, youtube dan sebagainya.

Periklanan dalam hal ini bukan hanya sebagai kegiatan pemasaran namun merupakan kegiatan komunikasi yang menekankan pada penyampaian pesan politik untuk mempersuasi, menstimulir orang agar bertindak. Dalam pemilukada DKI Jakarta, kedua pasangan yang akan "bertarung" tentnya akan merancang konsep dan perencanaan iklan yang matang. Guna menumbuhkan kesadaran yang kuat kepada khalayak, iklan yang dibuat haruslah seksama dengan mempertimbangkan pesan, media yang dipilih, strategi maupun logo yang mampu membentuk citra pada kandidat. Pesan yang disampaikan harus relevan, benar, dan tepat karena pesan merupakan konsep inti (core) proses komunikasi dalam pemilukada.

Iklan politik seringkali hanya dikaitkan dengan image saja. John Brabender (AdWeek, 2003: 20), konsultan iklan yang telah membuat lebih dari 200 mengemukakan jika realita yang ada menuntut iklan politik sekarang ini harus menampilkan semua produksi nilai dan rasa kreatifitas dari spot yang efektif untuk menjadi produk yang dikonsumsi-tetapi iklan politik harus dibaurkan menjadi bagian yang terbatas untuk ditampilkan di media. Dalam kajian umum, iklan biasanya dikemas secara komunikatif dan persuasif. Tokoh-tokoh politik menyadari betul bahwa iklan politik dapat mengorganisir wacana secara massif dan efisien. Padapilkada di ibukota Jakarta antara pasanganJoko Widodo-Basuki Tjahaja Purnama (Jokowi-Ahok) dan pasangan Fauzi Bowo-Nachrowi Ramli (Foke-Nara) ini dalam menyampaikan orasi melalui iklan di media internet. Banyak iklan politik internet yang menampilkan tentang apa-apa saja program kerja mereka.

Iklan politik itu sendiri merupakan bentuk aktivitas untuk menghadirkan dan mempromosikan individu maupun partai mereka, secara nonpersonal melalui media yang dibayar oleh sponsor tertentu. Dan berisikan muatan-muatan politik, seperti berisikan profil pribadi tokoh elit partai tersebut yang nantinya akan menarik minat pilih masyarakat kepada calon tersebut yang lebih dikenal masyarakat sehingga nantinya suara atas hak pilih masyarakat tersebut diberikankepada orang yang sering melihat iklan tersebut. Karena suatu iklan mampu memberikan pengaruh kepada 
khalayaknya yang dimana masyarakat yang tidak tau menjadi tau tentang sosok pemimpin yang akan menjadi ppemimpin mereka berikutnya. Karena kemampuan iklan tersebut JokowiAhok mampu menarik simpati masyarakat

Tren yang telah diciptakan oleh pasangan Jokowi-Ahok ini dengan iklan yang dibuat adalah mengenakan pakaian kotak-kotak yang efek ikutan-ikutan di Indonesia dinilai cukup tinggi. Ini adalah salah satu bentuk strategi yang cerdas dari Tim Kampanye Joko Widodo.Hal ini menarik untuk dikaji bagaimana peran iklan politik tersebut dalam menyampaikan pesan politik agar khalayak tertarik dan percaya terhadap calon kandidat. Pesan ini dapat dilihat dari efeknya. Kesuksesan Joko WidodoBasuki Tjahaja Purnama (Jokowi-Ahok) yang trennya meningkat dalam pilkada baik dalam putaran pertama maupun kedua. Ia berhasil meraih suatu jabatan tak lain karena kemampuannya menyampaikan pesan politik untuk membangun citra di media internet. Berdasarkan hal tersebut, akan menganalisis wacana yang ada pada iklan politik di media internet.

Rumusan masalah pada penelitian ini Bagaimana wacana pada isi pesan iklan politik Pemilihan Kepala Daerah DKI Jakarta yang disampaikan melalui media internet.

\section{KAJIAN TEORI}

\section{New Medium Theory}

Menurutgagasan

McLuhan (dalam Werner J dkk, 2011:458) bahwathemedium is the message, dimana media baru adalah pesan. Menurut Poster dan kawan-kawan (dalam Denis McQuail 2011:150) menggambarkan computer sebagai teknologi komunikasi yang secara unik tidak berdedikasi. Dalam pemikiran yang sama, Poster (dalam Denis McQuail 2011:150) intidari internet sebagai 'tidak berkarakter', tidak hanya keragaman serta ketidakpastian di masa depan, tetapi juga karena karakternya yang secara postmodern. Ia juga menunjukkan pada perbedaan utama dari penyiaran dan percetakan (perbedaan media baru dan media lama).

Media baru memberikan konsep pola komunikasi yang tidak ada batas antara penyampaian pesan dan penerimaan pean sehingga ruang media tersebut lebih mudah memberikan efek timbal balik. Secara dasar media baru internet hampir memiliki semua kebutuhan masyarakat. Pengguna Web terbiasa berfikir bahwa Web merupakana sumber informasi bebas dan dengan demikian kurang memperhatikan iklan padahalaman cetak.

\section{Iklan}

Iklan merupakan pesan bersifat verbal, dapat didengar ataupun visual, yang sponsor dapat diidentifikasi melalui satu atau beberapa media.Menurut Suhandang (2005) iklan dapat didefinisikan sebagai salah satu jenis teknik komunikasi massa dengan membayar ruangan atau waktu untuk menyiarkan informasi tentang barang dan jasa yang ditawarkan oleh si pemasang iklan.

Menurut Djaslim Saladin (2002:219) menyatakan bahwa "Advertising adalah salah satu alat promosi, biasanya digunakan untuk mengarahkan komunikasi persuasif pada pembeli sasaran dan masyarakat dimana bentuk penyajian iklan ini bersifat nonpersonal". 
Beberapa definisi yang dikemukakan oleh para ahli periklanan pada intinya bahwa iklan yang di tayangkan atau ditampilkan diberbagai media massa , berfungsi untuk memengaruhi pihak-pihak yang berkepentingan dengan produk atau jasa yang ditawarkan dalam iklan. Fungsi periklanan menjalankan sebuah fungsi informasi; ia mengomunikasikan informasi produk (calon kandidat), ciri-ciri dan lokasi penjualannya. Periklanan menjalankan sebuah fungsi persuasif yaitu mencoba membujuk para konsumen untuk membeli merek-merek tertentu atau mengubah sikap mereka terhadap produk (calon kandidat)atau perusahaan tersebut. Periklanan menjalankan sebuah fungsi pengingat yaitu terus menerus mengingatkan para konsumen tentang sebuah produk sehingga mereka akan tetap membeli produk yang diiklankan tanpa memerdulikan merek pesaingnya. Iklan merupakan pesan bersifat verbal, dapat didengar ataupun visual, yang sponsor dapat diidentifikasi melalui satu atau beberapa media.

\section{Iklan Politik}

Iklan politik merupakan bagian dari aktivitas pemasaran politik (political marketing). Pemasaran politik yakni serangkaian aktivitas terencana, strategis, dan taktis, berdimensi jangka panjang maupun pendek untuk menyebarkan makna politik kepada pemilih Sedangkan iklan politik merupakan iklan yang menawarkan sesuatu berkaitan dengan politik. Periklanan dalam hal ini bukan hanya sebagai kegiatan pemasaran namun merupakan kegiatan komunikasi yang menekankan pada penyampaian pesan politik untuk mempersuasi, menstimulir orang agar bertindak. Dalam pemilukada DKI Jakarta, kedua pasangan yang akan "bertarung" tentnya akan merancang konsep dan perencanaan iklan yang matang.

Menurut Bolland dalam Cangara (2009:345) mendefinisikan iklan politik " Iklan politik mengacu pada penggunaan dan pembelian ruang, waktu,dan spasi iklan yang dibayar untuk tarif komersial, dalam rangka memancarkan pesan politik kepada khalayak banyak" media yang digunakan banyak macam diantaranya media luar ruang ,media cetak ,media elektronik ,dan media internet .

Menurut Robert Baukus dalam cangara (2009:346) membagi iklan politik dalam empat macam yakni : Iklan serangan, yang ditujukan untuk mengdiskreditkan lawan;Iklan argumen ,yang memperlihatkan kemampuan para calon untuk mengatasi masalah masalah yang mereka hadapi ;Iklan ID , yang memberi pemahaman mengenai siapa sang calon kepada para pemili ;Iklan resolusi ,dimana para calon menyimpulkan pemikiran mereka untuk para pemilih.

Guna menumbuhkan kesadaran yang kuat kepada khalayak, iklan yang dibuat haruslah seksama dengan mempertimbangkan pesan, media yang dipilih, strategi maupun logo yang mampu membentuk citra pada kandidat. Pesan yang disampaikan harus relevan, benar, dan tepat karena pesan merupakan konsep inti (core) proses komunikasi dalam 
pemilukada. Kaitan internet sebagai media iklan politik adalah kekuatan media internet yang sekarang mulai digemari semua lapisan masyarakat untuk mendapatkan informasi lebih tentang kandidat politik di internet.

\section{Teks}

Pada dimensi teks, Fairclough membaginya ke dalam tiga elemen dasar, antara lain representasi, relasi, dan identitas. Representasi ini dilihat bagaimana peristiwa, orang, kelompok, atau apapun, disajikan dan digambarkan dalam teks. Representasi oleh Fairclough dapat dilihat dari dua hal. Yang pertama yaitu representasi dalam anak kalimat. Kedua, representasi dalam kombinasi anak kalimat. Ketiga, representasi dalam rangkaian antarkalimat. Relasi ini dilihat bagaimana hubungan antara wartawan, khalayak, dan partisipan ditampilkan dan digambarkan dalam teks.

Menurut Fairclough, paling tidak ada tiga kategori partisipan utama dalam media: wartawan (memasukkan di antaranya reporter, redaktur, pembaca berita untuk televisi dan radio), khalayak media, dan partisipan publik, memasukkan di antaranya politisi, pengusaha, tokoh masyarakat, artis, ulama, ilmuwan, para pendukung pasangan dan sebagainya. Identitas ini dapat dilihat bagaimana wartawan, khalayak, dan partisipan ditampilkan dan digambarkan dalam teks. Pada elemen ini, dilihat bagaimana identitas wartawan ditampilkan dan dikonstruksi dalam teks pemberitaan. Bagaimana wartawan menempatkan dan mengidentifikasi dirinya dengan masalah atau kelompok sosial yang terlibat.

\section{Metodologi Penelitian}

Dalam setiap penelitian, penentuan metode yang akan digunakan merupakan suatu keharusan. Hal ini penting karena metode berperan penting dalam menentukan keberhasilan pencapaian tujuan penelitian. Metode yang digunakan dalam penelitian ini adalah metode analisis wacana. Dimana penelitian ini meneliti objek penelitian yang akan penulis teliti adalah penggunaan bahasa yang dipakai pada wacana iklan politik pemilihan kepala daerah DKI Jakarta di media internet. Iklan politik di internet cukup menarik di teliti, karena bahasa yang digunakan kadang begitu singkat, sehingga mampu menarik perhatian kalayak pengguna internet dalam mengenal sosok calon kandidat lebih jauh.

Data primer dalam penelitian merupakan sumber data penelitian yang diperoleh secara langsung dari sumber asli (Sangadji. A.M \& Sopiah, 2010:171). Penelitian ini melakukan analisis wacana dalam iklan-iklan politik yang ada di internet.

Data sekunder merupakan data yang diperoleh dari catatancatatan dokumen dan juga sumber dari kepustakaan (Sangadji. A.M \& Sopiah, 2010:172). Peneliti memilih referensi beberapa buku dan website sebagai rujukan dan penguat data.

Dalam penelitian ini, peneliti menggunakan teknik sampling yang berdasarkan pada teori-teori yang digunakan.Teknik sampling yang digunakan adalah purposif sampling yang tujuanya untuk mendapatkan data 
secaralengkap. Purposif sampling sebenarnya bersifat selektif. Cuplikan purposiv sampling ini lebih cenderung mewakili informasinya dan tidak digunakan dalam rangka generalisasi atau sekeda rmewakili populasinya (GunawanWitjaksana,2011:14).

Teknik Pengumpulan data dikumpulkan melalui websitewebsite yang berhubungan dengan kampanye Cagub, terutama situs yang terkait dengan iklan-iklan politik.

Validitas data yang telahdigali, dikumpulkan, dicatat dalam penelitian harus diusahakan kevalidan dan kebenaranya. Karena itu peneliti harus memilih dan menemukan cara-cara yang tepat untuk mengembangkan data yang diperoleh. Cara-cara yang digunakan adalah trianggulasi atau review informan. Dalam penelitian ini penelitian melihat sesuatu yang sama dari perspektif yang berbeda. Menurut Patton (dalam Gunawan Witjaksana, 2011:24) teknik yang sering disebut trianggulasi sumber mengarahkan agar dalam mengumpulkan data, penelti wajib menggunakan beberapa sumber yang tersedia. Artinya data yang sama akan lebih mantap kebenaranya jika digali dari beberapa sumber yang berbeda. Dengan demikian apa yang ditulis dari sumber satu, bias lebih teruji kebenaranya jika dibandingkan dengan data lain yang memperoleh dari sumber yang berbeda baik kelompok sumber sejenis ataupun sumber-sumber yang berbeda jenis.

\section{Hasil Dan Pembahasan}

1. Iklan Politik di Internet
Pengiklan berbondongbondong menuju ke situs-situs internet ketika pertama kali internet didirikan. Mereka mengharapkan mendapat respon dengan cepat seperti banyaknya konsumen yang menggunakan internet. Pengiklan biasanya menggunakan iklan banner yang berarti pesan iklan mereka mengalir pada situs Web atau muncul dalam sebuah kotak pada situs. Pengiklan belajar dengan cepat, namun tidak peduli bagaimana mereka mengemas pesan.

Kesempatan ini juga dimanfaatkan oleh para elit politik untuk menaikan rating citra mereka. Para elit dalam politik memanfaatkan pencalonan diri mereka dengan menggunakan iklan di internet untuk mendapatkan respon lebih banyak. Iklan politik di internet juga tidak memerlukan biaya yang cukup banyak. Bagi partai politik dan kandidat politik, periklanan dapat mempengaruhi dan menjaring pemilih. Sementara pemilih berharap bisa mendapatkan informasi yang akan digunakan sebagai bahan pertimbangan dalam memilih.

Masing-masing kandidat benar-benar memanfaatkan kekuatan untuk memasang iklan politik. Kandidat tidak hanya menggunakan iklan di media massa tetapi sampai kepada media luar ruang, yakni spanduk, poster, baliho dan masih banyak bentuk yang lain.Pengaruh iklan dalam kehidupan politik sangatlah besar. Iklan mempunyai kemampuan untuk mempengaruhi opini publik dan perilaku masyarakat. Hal ini menjadi sangat penting dalam kampanye partai politik. Cakupan yang luas dalam masyarakat 
membuat iklan dianggap sebagai salah satu cara yang efektif dalam mengkomunikasikan program kerja, pesan politik, pembentukan image partai atau individu.

\section{Analisis Wacana Iklan Politik Jokowi - Ahok di Internet}

Pada representasi disini dapat dianalisis penggunaan kata pada teks iklan politik di internet pasangan Jokowi-Ahok ini sangat singkat. Iklan ini memiliki representasi yang memiliki konotasi yang lebih menimbulkan semangat dibandingkan dengan kata "Era". Jokowi yang digambarkan memiliki hubungan baik dengan masyarakat Solo sewaktu masih menjabat menjadi walikota. Kata "Gebrakan" tersebut mengindikasikan kesetaraan.

Representasi kombinasi anak kalimat pada iklan mengenai kesehatan Jokowi mampu menarik simpati masyarakat. Kata sambung relatif yang digunakan untuk memperinci dan menguraikan bagaimana mudahnya masyarakat kurang mampu Jakarta untuk bisa pergi ke puskesmas atau ke rumah sakit. Sosok Jokowi - Ahok menjadi sangat digemari karena dalam iklannya mereka mampu memberi kepercayaan kepada masyarakat.

Relasi ini dilihat bagaimana hubungan antara wartawan, khalayak, dan partisipan ditampilkan dan digambarkan dalam teks. Menurut Fairclough, paling tidak ada tiga kategori partisipan utama dalam media: wartawan (memasukkan di antaranya reporter, redaktur, pembaca berita untuk televisi dan radio), khalayak media, dan partisipan publik, memasukkan di antaranya politisi, pengusaha, tokoh masyarakat, artis, ulama, ilmuwan, para pendukung pasangan dan sebagainya. Pada iklan "Gubrakan Jokowi" terdapat teks dimana Jokowi melakukan relasi dengan lembaga media yaitu kompas.com. Dimana Jokowi memasukkan partisipan yang mereka ajak untuk bekerjasama dalam menyampaikan orasi politiknya dengan lembaga media tersebut.

Identitas Jokowi - Ahok mendapat porsi lebih dalam iklan ini. Lebih dari sekadar walikota Solo, tetapi juga untuk membuka dan menunjukkan sosoknya yang bisa mengajak khalayak Jakarta dalam mengatasi permasalahan yang ada.

\section{Pembahasan}

Menurut Fairclough analisis wacana merupakan sebuah praktik sosial, yang membagi analisis wacana kedalam tiga dimensi yaitu text, discourse practice, dan social practice. Text berhubungan dengan linguistik, discourse practice berhubungan dimensi yang berhubungn dengan proses produksi dan konsumsi teks, sedangkan social practice berhubungan dengan konteks di luar teks. Fairclough yang melihat teks (naskah) memiliki konteks. Peneliti melakukan analisis wacana dengan pandangan kritis.

Isi pesan iklan politik di internet terkadang memiliki teks yang memiliki arti yang sama seperti calon kandidat yang lain.Pasangan Jokowi-Ahok dalam menampilkan iklan mereka di internet memiliki teks yang membuat pengguna internet penasaran.

Pada teks ada beberapa elemen yang pertama representasi, dilihat bagaimana peristiwa, orang, kelompok, atau apapun, disajikan dan digambarkan dalam teks. 
Selanjutnya pada elemen relasi ini dilihat bagaimana hubungan antara wartawan, khalayak, dan partisipan ditampilkan dan digambarkan dalam teks. Dalam elemen identitas ini dapat dilihat bagaimana wartawan, khalayak, dan partisipan ditampilkan dan digambarkan dalam teks. Pada elemen ini, dilihat bagaimana identitas wartawan ditampilkan dan dikonstruksi dalam teks pemberitaan. Bagaimana wartawan menempatkan dan mengidentifikasi dirinya dengan masalah atau kelompok sosial yang terlibat.

Isi pesan iklan politik pemilihan kepala daerah DKI Jakarta Jokowi-Ahok di internet menurut teori media baru (new medium theory) (Denis McQuail 2011:150) mampu mempengaruhi bagaimana cara berfikir khalayak dalam merespon iklan tersebut. Iklan yang bertemakan "Gebrakan Jokowi" ini mampu menarik khalayak untuk ikut serta berinteraksi dalam cara yang lain seperti para penggemar Jokowi menjual baju kotak-kotak ala Jokowi, dan membuat iklan video parodi mereka. Konsep pola komunikasi yang diberikan media baru tidak ada batasnya sehingga iklan politik pemilihan kepala daerah DKI Jakarta mampu menyampaikan pesan dan diterima khalayak. Iklan politik Jokowi-Ahok memanfaatkan media baru untuk menyampaikan pesan politik yang mereka bangun. Pada iklan politik ini Jokowi-Ahok dalam pemilihan teks yang mereka sajikan lebih singkat, tegas, dan lugas. Karena media baru internet ini lebih banyak digunakan oleh kalangan muda dan orang-orang yang bekerja. Penggunaan teks pada iklan ini lebih terlihat pasti dan tidak menebar janji semata.

Wacana lisan yang digunakan dalam iklan mengusung tema Gebrakan Jokowi dengan menampilkan sosok Jokowi - Ahok. Iklan ini lebih terpusat pada pengenalan Jokowi. kata-kata "Gubrakan Jokowi" yang disampaikan sebagai kinerja yang akan membawa perubahan pada Jakarta. Kata Gubrakan disini mengajak khalayak untuk mengenal lebih dalam lagi mengenai sosoknya melalui kinerjanya.

\section{Kesimpulan}

Isi pada iklan politik Jokowi -Ahok dalam penggunaan kata-kata dalam pemilihan teksnya sangat singkat, tegas dan mampu menarik simpati masyarakat. Secara intertekstual, iklan politikJokowiAhok menggunakan unsur-unsur teks atau peristiwa lain untuk membentuk perspektif baru bagi penguna internet. Dimana iklan politik Jokowi-Ahok di internet juga mampu menarik minat masyarakatnya, selain sosok Jokowi yang dikenal dengan tata cara bicara yang tenang.

Iklan politik pemilihan kepala daerah DKI Jakarta di internet oleh pasangan JokowiAhok ditemukan bahwa iklan politik cukup memberikan pengaruh di tengah-tengah perspektif masyarakat yang menilai iklan politik hanya berisi janji-janji semata. Itu pulalah yang tampak pada teks iklan. Penggunaan teks pada iklan politik di internet, sangat berperan besar. Pemilihan tema yang sesuai dengan kondisi bangsa. 
Daftar Pustaka

Akhyar Lubis. 2004. Masih Adakah

Tempat Berpijak Bagi

Ilmuwan. Bogor: Akademia.

Alex Sobur 2006. Analisis Teks Media; Suatu Pengantar untuk Analisis Wacana, Analisis Semiotika, dan Analisis Framing. Bandung: PT. Remaja Rosdakarya.

Aris Badara. 2012. Analisis Wacana, "Teori, Metode, dan Penerapanya pada Wacana Media. Jakarta: Kencana Prenada Media Group.

Biagi, Shirley, 2010. Media Impact: An Introduction to Mass Media, 9th ed. Penerjemah: Mochammad Irfan dan Wulung WiraMahendra. Edisi 9.2010. Media Impact:Jakarta. Salemba.

Dan, Nimmo. 2001. Political Communication and Public Opinion and America. Penyunting: Jalaluddin Rakhmat, M.Sc. Penerjemah: Tjun Surjaman. Bandung: PT. Remaja Rosdakarya.

Deddy Mulyana. 2001. Ilmu Komunikasi; Suatu Pengantar. Bandung: PT. Remaja Rosda Karya. 2001, Metodologi

Penelitian Kualitatif (Paradigma Baru Komunikasi dan Ilmu Sosial Lainnya). Bandung: Remaja Rosdakarya.

Djaslim Saladin. 2002. Manajemen Pemasaran, PT. Linda Karya Bandung. dan Yavis Marty Oesman. 2002. Intisari Pemasarn dan Unsur-unsur
Pemasaran. PT. Linda Karya.

Fandy Tjiptono. 2008. Strategi Pemasaran Edisi Ketiga. Andi. Yogyakarta.

Fisher, B. Aubrey, 1986, Teori-teori Komunikasi. Penyunting: Jalaluddin Rakhmat, Penerjemah: Soejono Trimo. Bandung: Remaja Rosdakarya.

Gunawan Witjaksana. 2011. Metodologi Penelitian Kualittif. Semarang: Universitas Semarang.

Hafied Cangara. 2003. Pengantar Ilmu Komunikasi. Jakarta: PT. Raja Grafindo Persada. 2009, Komunikasi

Politik , Jakarta : PT Rajagrafindo Persada.

Soeseno Kartomihardjo. 1993. Analisis Wacana dengan Penerapan pada Beberapa Wacana, dalam Bambang Kaswanti Purwo (Editor). PELLBA 6.Yogyakarta Kanisius.

KustadiSuhandang. 2005, Periklanan : Manajemen, Kiat dan Strategi, Nuansa, Bandung.

Kotler, Philip, 2005, Manajemen Pemasaran, Terjemahan oleh Benyamin Molan, Jilid 2, Edisi kesebelas, Penerbit PT INDEKS Kelompok Gramedia,Jakarta.

Littlejohn. W, Stephen dan Karen

A. Foss. 2009. Teori Komunikasi. Edisi 9. Jakarta Salemba Humanika.

McQuail,Denis, "Political Communication" dalam Maurice Kogan (eds.), Handbook of Politics Vol. 1. London: Routledge, 1992. 
Mass

Communication Theory 4th

ed,

London:Sage

Publications, 2002.

Meadow, Robert G, 1980. Political As

Communication,

Noorwod, NJ: ablex Publishing Company.

Nunan, David. 1993.Introducing Discourse Analysis. London:Pinguin Book.

Rachmat Kriyantono. 2006. Teknik Praktis Riset Komunikasi: Disertai Contoh Praaktis Riset Media, Public Relations, Advertising, Komunikasi Organisasi, Komunikasi Pemasaran. Jakarta: Prenada

Media Suyanto, Bagong dan Sutina. Cetakan ke-3,September. 2007. Metode Penelitian Sosial: Berbagai Alternatif Pendekatan. Jakarta. Kencana.

Sutopo, H.B. 2002. Metodologi Penelitian Kualitatif. Sebelas Maret University Press. Sutopo, H.B. 2002. Metodologi Penelitian Kualitatif. Sebelas Maret University Press.

Severin, Werner J., James W. Tankard,Jr. 2001.Teori Kommunikasi: Sejarah, Metode, \& Terapan Di Dalam Media Massa,Edisi Kelima. Jakarta:Kencana Prenada Media Group.

Pawito, Ph.D. Komunikasi Politik: Media Massa dan Kampanye Pemilihan. Yogyakarta: Jalasutra

Pavlik, Jhon V., dan Everette E. Dennis. 1996. New Media Technology, Cultural and Comercial Perspective,
Allyn and Bacon.

Singapore.

Artikel : Sangadji. E.M. \& Sopiah. 2010. Metodologi

Penelitian. Yogyakarta: Andi Offset. (http://indovasi.org/launchin g-game-selamatkan-jakartajokowi-basuki/, pada tanggal 5 Mei 2013, jam 14.29 WIB.

Artikel "Pengaruh Pemasangan Iklan Politik 2012"; diunduh dari situs internet http://ariefmustofa.blogspot. com/"; pada tanggal 20 Desember 2012"; jam 21.00 WIB.

Artikel "Hasil Survei Pendukung foke-stabil Jokowi meningkat 2012"; diunduh dari situs internet http://www.solopos.com/"; pada tanggal 16 Desember 2012"; jam 13.00 WIB.

Website" http://www.lib.uinsuka.ac.id/", pada tanggal 10 Mei 2013; jam 18.00 WIB. 